\title{
Streptococcus agalactiae $\beta$ gene and gene product variations
}

\author{
J. A. MAELAND, O. G. BRAKSTAD, ${ }^{*}$ L. BEVANGER and A. I. KVAM \\ Department of Microbiology, School of Medicine, Norwegian University of Science and Technology, N-7006, \\ Trondheim and * SINTEF Applied Chemistry, N-7034, Trondheim, Norway
}

\begin{abstract}
Streptococcus agalactiae (group B streptococci; GBS) are serotyped on the basis of the capsular polysaccharide antigens and subtyped on the basis of the strain-variable and surface-localised $\mathrm{c}$ proteins $\mathrm{c}^{\alpha}, \mathrm{c}^{\beta}$, and $\mathrm{R}$ proteins. This study compared $\mathrm{c}^{\beta}$ protein detection and the polymerase chain reaction (PCR) for $\beta$ gene detection, by examining 50 clinical GBS strains. The $\mathrm{c}^{\beta}$ protein was detected by antibody-based immunofluorescence in a GBS whole-cell assay and Western blotting by probing with the anti-c $\beta$ antibody or human IgA. Absorption experiments were performed to test for surfaceanchoring of $\mathrm{c}^{\beta}$; and bacterial supernates were examined to test for $\mathrm{c}^{\beta}$ production. Primers for the PCR target regions resulted in a 620-bp product that included $\beta$ geneencoding IgA-binding domains. The results demonstrated four categories of GBS with respect to the $\beta$ gene and the $c^{\beta}$ protein: (1) strains (16 of 50) that harboured the $\beta$ gene and regularly expressed normal surface-localised $c^{\beta}$ with a $M_{\mathrm{r}}$ of $120 \mathrm{kDa}$; (2) strains (5 of 50) that harboured the gene but did not express the protein; (3) strains (2 of 50) that harboured the gene but expressed a $c^{\beta}$ that was not surface-localised and had reduced $M_{r}$; (4) strains (27 of 50) without $\beta$ gene and $c^{\beta}$ expression. One strain amongst the third group generated a PCR product of $1330 \mathrm{bp}$. These results demonstrate considerable strain variability of the $\beta$ gene of GBS and of its product the $c^{\beta}$ protein.
\end{abstract}

\section{Introduction}

Streptococcus agalactiae (group B streptococcus; GBS) is an important cause of invasive disease in neonates, of pregnancy-associated disease in women, and of nonpregnancy-related disease in adults [1]. Serological classification of GBS plays an important role in their epidemiological study. GBS can be serotyped on the basis of the capsular polysaccharide ( $\mathrm{CHO}$ ) antigens and subtyped on the basis of strain-variable proteins which are bound to the bacterial cell surface. The surface-anchored proteins include the c proteins $\mathrm{c}^{\alpha}$ and $\mathrm{c}^{\beta}$ and the $\mathrm{R}$ proteins. In addition, two other protein antigens, $\gamma$ and $\delta$, have also been described within the $c$ protein fraction [2]. Immunoprecipitation or fluorescent antibody testing (FAT) are commonly used to detect both the $\mathrm{CHO}$ antigens and the protein antigens with polyclonal or, increasingly, monoclonal antibodies (MAbs). MAbs have been generated for $\mathrm{c}^{\alpha}[3,4], \mathrm{c}^{\beta}$ [5], the R4 protein [6], and for some of the capsular CHO antigens [7]. Recently, GBS isolates from England and Norway were serotyped and subtyped,

Received 7 March 1997; accepted 23 April 1997. Corresponding author: Professor J. A. Maeland. the latter being performed with anti-c $\mathrm{c}^{\alpha},-\mathrm{c}^{\beta}$ and $-\mathrm{R} 4$ MAbs in a FAT. This revealed a total of 29 GBS serovariants among the 334 isolates examined [8]. The protein $\mathrm{c}^{\alpha}$ occurred in $45.5 \%$ of the isolates, $\mathrm{c}^{\beta}$ in $24.3 \%$, and $\mathrm{R} 4$ in $32.3 \%$ [8]. In addition to their importance as sero-subtype markers, the surfacelocalised proteins may function as virulence factors $[9,10]$ and they appear to be targets for protective antibodies in experimental infections $[4,11,12] . \mathrm{c}^{\beta}$ also has the ability to bind human $\operatorname{IgA}$ by its $\mathrm{Fc}$ fragment [13].

The present study focused on $\mathrm{c}^{\beta}$ and the $\beta$ gene, which has been sequenced $[14,15]$. The gene encodes a protein with an $\mathrm{N}$-terminal signal sequence $(\mathrm{S})$, two IgA-binding domains (A and $\mathrm{B}$ ), a cell wall-spanning domain (W), and a membrane-spanning domain (M) on the C-terminal side of the protein [15]. Domain A on the $\mathrm{N}$-terminal side is responsible for most of the IgA-binding capacity of $\mathrm{c}^{\beta}$ [16]. Recent studies have demonstrated variability among GBS isolates in surface-anchoring of $\mathrm{c}^{\beta}$ and in its ability to bind the $\mathrm{Fc}$ region of human $\operatorname{IgA}[17]$.

The present study examined 50 GBS isolates from 
neonatal and adult infections by antibody-based techniques for $\mathrm{c}^{\beta}$ protein detection and by PCR-based methods for $\beta$ gene detection.

\section{Materials and methods}

\section{Bacterial strains examined}

A total of 50 GBS strains was analysed. The isolates were from adult and neonatal infectious disease cases in different Norwegian hospitals and had been forwarded to this laboratory for serotyping. All isolates had been included in a previous study of GBS serotype distribution [8]. Strains of the $\mathrm{CHO}$ antigen types Ia $(\mathrm{n}=21)$, Ib $(\mathrm{n}=13)$ and II $(\mathrm{n}=16)$ were arbitrarily chosen from the strain collection to provide a suitable number for the purpose of this study. Amongst this collection, strains FAT positive $(n=16)$ or negative $(\mathrm{n}=34)$ for $\mathrm{c}^{\beta}$ protein production were included. The strains A909 (serotype $\mathrm{Ia} / \mathrm{c}^{\alpha \beta}$ ) and 46/94 (II) were used as positive and negative control strains for $c^{\beta}$ production. Bacteria were preserved in Greaves's medium at $-80^{\circ} \mathrm{C}$ and were cultured on blood agar plates or in Todd-Hewitt broth as described previously [18].

\section{$M A b$}

Generation and characterisation of the anti-c $\mathrm{c}^{\beta} \mathrm{MAb}$ (IgG $1 / \kappa$ isotype) have been described previously [5]. The antibody had a titre of $10^{6}$ in a GBS whole-cell ELISA [5].

\section{Polyclonal anti-c ${ }^{\beta}$ serum}

Protein $\mathrm{c}^{\beta}$ from GBS strain $15626\left(\mathrm{IV} / \mathrm{c}^{\beta}\right)$ was prepared by $\mathrm{HCl}$ extraction [18] of the bacteria and purified by affinity chromatography with $\mathrm{CNBr}$-activated Sepharose (Pharmacia, Uppsala, Sweden) with bound IgG isolated from rabbit antiserum against $\mathrm{c}^{\beta}$ protein [3]. Immunisation of rabbits was performed as described previously [3].

\section{FAT}

Slides with GBS were prepared and the tests were performed and interpreted as described previously [8, 19].

\section{Indirect ELISA}

Todd-Hewitt broth supernates of cultured GBS A909 were used for coating after precipitation with trichloroacetic acid, $5 \% \mathrm{w} / \mathrm{v}$, solubilisation of the precipitate in phosphate-buffered saline (PBS) $\mathrm{pH} \mathrm{7.2,} \mathrm{in} \mathrm{a} \mathrm{volume}$ that corresponded to a 100 -fold concentration of the supernate, followed by dialysis against PBS. The optimal coating dilution was determined by titration of the anti-c $\mathrm{c}^{\beta}$ MAb. ELISA was performed as described previously [5] with peroxidase-labelled rabbit anti- bodies against murine immunoglobulins (Dakopatts, Glostrup, Denmark) and colour development with $o$ phenylendiamine- $\mathrm{H}_{2} \mathrm{O}_{2}$. The reaction was stopped after $10 \mathrm{~min}$ and $\mathrm{OD}_{495}$ was recorded. In probing with rabbit anti-c $\mathrm{c}^{\beta}$ serum, antibody binding was detected with peroxidase-conjugated swine anti-rabbit $\operatorname{IgG}(1$ in 1000; Dakopatts).

\section{Sandwich ELISA}

A sandwich ELISA was used to detect $\mathrm{c}^{\beta}$ in concentrated fluid culture supernates. Coats for $\mathrm{c}^{\beta}$ capture were prepared with human $\operatorname{IgA}(5 \mu \mathrm{g} / \mathrm{ml}$; Sigma). After washing and blocking [5], concentrated supernates which were diluted 1 in 2 in PBS with Tween $20 \quad 0.05 \% \quad \mathrm{v} / \mathrm{v}$ (PBS-T) were applied and incubated $\left(20^{\circ} \mathrm{C} ; 1 \mathrm{~h}\right)$. After washing, captured $\mathrm{c}^{\beta}$ was detected with the anti-c ${ }^{\beta}$ MAb or the rabbit antiserum as described for the indirect ELISA. The OD recordings were matched against those recorded when concentrated supernates of the positive (strain A909) and negative control strain (strain 46/94) were tested.

\section{Immunoblotting}

Components of SDS-lysed bacteria were separated by SDS-PAGE with polyacrylamide $12 \%$ gels and transferred on to PVDF membranes (BioRad, Richmond, CA, USA), pore size $0.2 \mu \mathrm{m}$, as described previously [3]. The membranes were processed for probing with the anti-c ${ }^{\beta}$ MAb (1 in 1000), rabbit anti-c ${ }^{\beta}$ serum (1 in $1000)$ or human $\operatorname{IgA}(5 \mu \mathrm{g} / \mathrm{ml})$. Immunoglobulin binding was detected with peroxidase-labelled antisera as in ELISA or peroxidase-laballed goat antibody to human IgA (1 in 1000; Sigma) and colour development with $o$-phenylenediamine- $\mathrm{H}_{2} \mathrm{O}_{2}$.

\section{Absorption}

GBS cell deposits were pelleted, washed with PBS, and adjusted to $c$. $10^{10} \mathrm{cfu} / \mathrm{ml}$ in PBS. Equal volumes of the suspension and the anti-c ${ }^{\beta}$ MAb (1 in 2000) or rabbit antiserum ( 1 in 1000) in PBS-T, were mixed and incubated at $20^{\circ} \mathrm{C}$ for $1 \mathrm{~h}$. Bacteria were pelleted $(2000 \mathrm{~g}, 10 \mathrm{~min})$ and the supernate was tested in ELISA for anti-c ${ }^{\beta}$ activity, with coats prepared with concentrated culture supernate of strain A909.

\section{Primers and probe}

Oligonucleotides were synthesised (Med Probe, Oslo, Norway) on the basis of published sequences of the $\beta$ gene [15]. The two 24-mer primers corresponded to the nucleotides 1337-1360 (5'-AAGGCTATGAGTGAGAGCTTGGAG-3') and 1917-1940 (5'-CTGCTCTGGTGTTTTAGGAACTTG-3'), respectively. These primer positions resulted in a deduced amplification product of $604 \mathrm{bp}$ which included a part of each of the $\operatorname{IgA}$ binding domains $\mathrm{A}$ and $\mathrm{B}$ [15]. For hybridisation, an internal 39-mer probe targeting the nucleotide position 
1686-1724 (5'-CAGTCACAGCTAAAAGTGATTCGAAGACGACGTTGGACT- $3^{\prime}$ ) of the $\beta$ gene [15] was synthesised. The probe was biotin-labelled in the $5^{\prime}$ end. Probe and primers were used without further purification and were preserved as described previously [20].

\section{PCR amplification}

Overnight broth cultures of GBS were diluted 1 in 10 in saline and $100 \mu \mathrm{l}$ were centrifuged $(11000 \mathrm{~g}$; $5 \mathrm{~min}$ ). The pellet was washed three times in saline, suspended in $100 \mu \mathrm{l}$ of deionised water, and $10 \mu \mathrm{l}$ of the suspension were added to $90 \mu 1$ of Chelex-100 lysis reagent: Chelex-100 (Bio-Rad) 15\% w/v, Tween $201 \%$ $\mathrm{v} / \mathrm{v}$ and Nonidet P-40 1\% v/v in autoclaved ultra-pure water. The mixture was heated $\left(95^{\circ} \mathrm{C} ; 15 \mathrm{~min}\right)$, diluted 1 in 10 in deionised water and $10 \mu \mathrm{l}$ were mixed with $88 \mu \mathrm{l}$ of the PCR mixture: $2 \mu 1(10 \mathrm{mM})$ of each of the nucleotides dATP, dGTP, dTTP and dCTP, $0.4 \mu \mathrm{l}$ $(200 \mathrm{mM})$ of each of the primers, $10 \times$ PCR amplification buffer (Boehringer Mannheim) and $69.2 \mu 1$ of deionised water in thin-walled reaction tubes and with 2 drops of sterile mineral oil overlaid. After heating at $94^{\circ} \mathrm{C}$ for $5 \mathrm{~min}, 2 \mu \mathrm{l}$ of $\mathrm{Taq}$ DNA polymerase $(2.5 \mathrm{U}$; Boehringer Mannheim) were added and the mixture was run in a DNA thermal cycler (Perkin-Elmer Cetus Corp., Norwalk, CT, USA) which had been prewarmed to $94^{\circ} \mathrm{C}$. A total of $37 \mathrm{PCR}$ cycles were run at $94^{\circ} \mathrm{C}$ (1 $\mathrm{min})$ for denaturation, $60^{\circ} \mathrm{C}(1 \mathrm{~min})$ for primer annealing, and $72^{\circ} \mathrm{C}(1 \mathrm{~min})$ for DNA extension. The reaction was terminated at $4^{\circ} \mathrm{C}$ and PCR products were detected by agarose gel electrophoresis with agarose $2 \%$ gels as described previously [20].

\section{Southern blot analysis}

Agarose gel-separated PCR products were transferred to a Zeta Probe blotting membrane (BioRad) as described previously [20]. The membranes were processed for hybridisation as described [20], and were hybridised in a hybridisation oven at $50^{\circ} \mathrm{C}$ for $60 \mathrm{~min}$ in a hybridisation solution [20] which contained 1 pmol of the biotinylated DNA probe. The membrane was washed twice $(5 \mathrm{~min}$; $20^{\circ} \mathrm{C}$ ) in a washing solution [20], incubated at $20^{\circ} \mathrm{C}$ for $60 \mathrm{~min}$ with a streptavidin-peroxidase conjugate ( 1 in 2000; Sigma), washed in PBS-Tween 20, and developed with $o$-phenylendiamine- $\mathrm{H}_{2} \mathrm{O}_{2}$.

\section{Results}

All 50 GBS strains included in the present study, previously tested by an anti-c $\mathrm{c}^{\beta}$ MAb-based FAT [8], were examined by PCR ( $\beta$-PCR) for $\beta$ gene detection (Table 1). All 16 strains FAT-positive for $\mathrm{c}^{\beta}$ were also $\beta$-PCR positive. Of the $16 \mathrm{FAT}^{+} / \beta-\mathrm{PCR}^{+}$isolates, strains $3-8$ shown in Table 2 were selected for further investigation. The remaining $\mathrm{FAT}^{+} / \beta-\mathrm{PCR}^{+}$isolates were not examined further.

Fig. 1 shows $\beta$-PCR and Western blot results with the positive (no. 1) and negative (no. 2) control isolates and strain nos. 3-8. All strains except the negative control generated a PCR product of $620 \mathrm{bp}$, which is close to the theoretical estimate of $604 \mathrm{bp}$. In immunoblotting, these strains showed a major band calculated at $c .120 \mathrm{kDa}$ and a variable number of more weakly stained bands when probed with the anti$\mathrm{c}^{\beta}$ MAb. Thus, the strains shown in Fig. 1 produced quite similar results in the FAT and Western blotting

Table 1. Correlation of $\mathrm{c}^{\beta}$ protein production tested by the FAT and PCR for $\beta$ gene detection

\begin{tabular}{lcc}
\hline & \multicolumn{2}{c}{ Number of strains } \\
\cline { 2 - 3 }$\beta$-PCR & FAT-positive & FAT-negative \\
\hline Positive & 16 & 7 \\
Negative & 0 & 27 \\
\hline
\end{tabular}

Table 2. Designation, serotype and results obtained in the FAT, $\beta$-PCR and Western blotting with GBS isolates

\begin{tabular}{|c|c|c|c|c|c|c|}
\hline \multirow[b]{2}{*}{ Strain no. } & \multirow{2}{*}{$\begin{array}{c}\text { Strain } \\
\text { designation }\end{array}$} & \multirow[b]{2}{*}{ Serotype } & \multirow[b]{2}{*}{ FAT $^{*}$} & \multirow[b]{2}{*}{$\beta$-PCR } & \multicolumn{2}{|c|}{ Western blotting with } \\
\hline & & & & & MAb* & $\operatorname{IgA}$ \\
\hline $1^{\dagger}$ & A909 & $\mathrm{Ia} / \mathrm{c}^{\alpha \beta}$ & + & + & + & + \\
\hline $2^{\ddagger}$ & $46 / 94$ & II & - & - & - & - \\
\hline 3 & $161616 / 92$ & $\mathrm{Ia} / \mathrm{c}^{\alpha \beta}$ & + & + & + & + \\
\hline 4 & $114007 / 92$ & $\mathrm{Ia} / \mathrm{c}^{\alpha \beta}$ & + & + & + & + \\
\hline 5 & $19 / 94$ & $\mathrm{Ib} / \mathrm{c}^{\alpha \beta}$ & + & + & + & + \\
\hline 6 & $14 / 95$ & $\mathrm{Ib} / \mathrm{c}^{\beta}$ & + & + & + & + \\
\hline 7 & $3 / 94$ & $\mathrm{II} / \mathrm{c}^{\beta}$ & + & + & + & + \\
\hline 8 & $26 / 94$ & $\mathrm{II} / \mathrm{c}^{\beta}$ & + & + & + & + \\
\hline 9 & $23 / 94$ & $\mathrm{Ia} / \mathrm{c}^{\alpha}$ & - & + & - & - \\
\hline 10 & $45 / 95$ & Ia & - & + & - & - \\
\hline 11 & $13 / 94$ & $\mathrm{Ib} / \mathrm{c}^{\alpha}$ & - & + & - & - \\
\hline 12 & $56 / 94$ & $\mathrm{Ib} / \mathrm{c}^{\alpha}$ & - & + & - & - \\
\hline 13 & R90/1653 & $\mathrm{Ib}$ & - & + & - & - \\
\hline 14 & $31 / 94$ & II & - & + & + & + \\
\hline 15 & $23 / 95$ & IIc $^{\alpha}$ & - & + & + & + \\
\hline
\end{tabular}

With an anti-c ${ }^{\beta} \mathrm{MAb}$

† Positive control strain.

${ }^{\star}$ Negative control strain. 

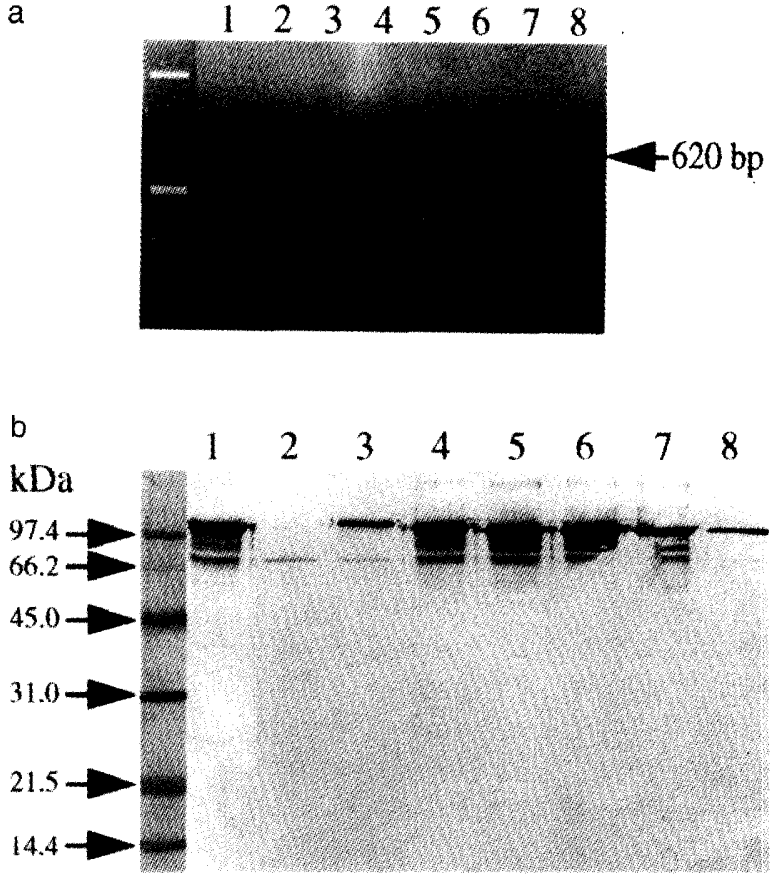

Fig. 1. Gel electrophoresis of PCR products of the amplified $\beta$ gene of GBS strains (a) and Western blots of SDS-lysates of whole cell of the same strains probed with an anti-c $\mathrm{c}^{\beta} \mathrm{MAb}(\mathbf{b})$. Strains analysed are indicated at the top of each lane (see Table 2).

for $\mathrm{c}^{\beta}$ detection and in the $\beta$-PCR for $\beta$ gene detection. The PCR product of these strains hybridised to the internal DNA probe (not shown).

Of the 34 FAT-negative strains, seven produced an amplification product in the $\beta$-PCR (Table 1). These strains are listed as nos. 9-15 and included capsular type Ia, Ib, and II GBS (Table 2). Six of the seven strains generated a 620-bp PCR product and one type II strain (no. 14) a 1330-bp product (Fig. 2a). The tests were repeated twice at an interval of several weeks and the results were reproducible. The PCR products were tested in a Southern hybridisation assay. The internal DNA probe hybridised to the PCR product of the $\mathrm{FAT}^{-} / \beta-\mathrm{PCR}^{+}$strains with the exception of strain no. 14, which generated the 1330-bp product (Fig. 2b). Concordant results were obtained when the amplification mixtures were tested in a dot hybridisation assay (data not shown).

When strain nos. 9-15 were probed in immunoblotting against the anti-c ${ }^{\beta}$ MAb only two (nos. 14 and 15) showed antibody binding, resulting in major lines of c. $94 \mathrm{kDa}$ and c. $84 \mathrm{kDa}$, respectively (Fig. 2c), well below the $\mathrm{M}_{\mathrm{r}}$ of 'normal' $\mathrm{c}^{\beta}$. Strains were tested for binding of human IgA by its $\mathrm{Fc}$ fragment by Western blotting. The positive control GBS strain A909 and the $\mathrm{FAT}^{+} / \beta$-PCR ${ }^{+}$strain nos. 3-8 showed IgA-binding as expected, resulting in banding patterns similar to those obtained with the MAb (not shown). Also, the $\mathrm{FAT}^{-} / \beta$-PCR ${ }^{+}$strain nos. 14 and 15 bound IgA resulting in banding patterns similar to those that a

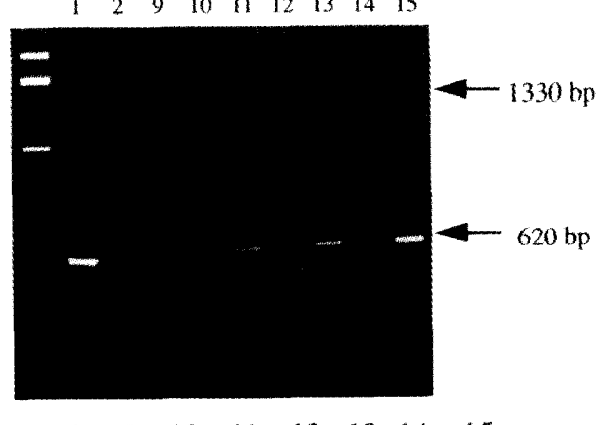

$\begin{array}{lllllllll}1 & 2 & 9 & 10 & 11 & 12 & 13 & 14 & 15\end{array}$
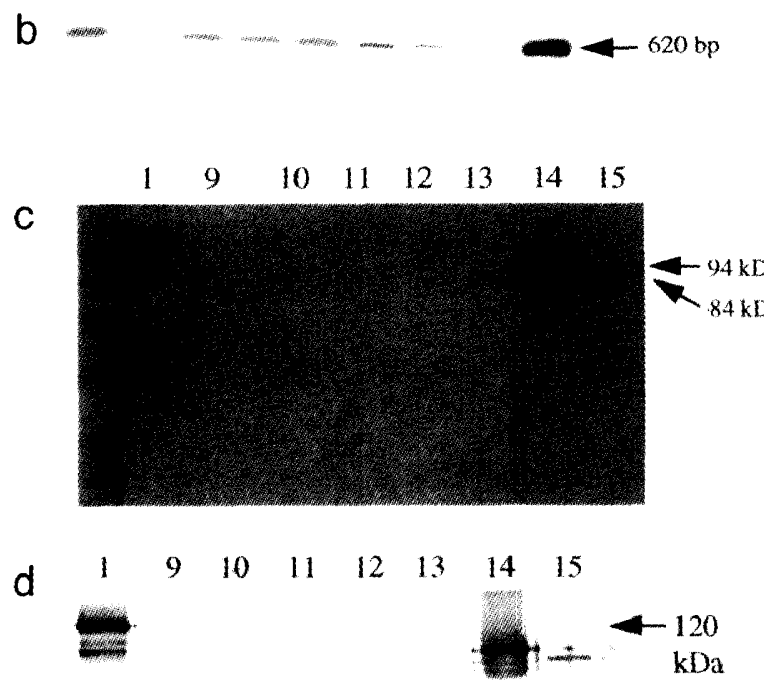

Fig. 2. GBS strains tested for PCR products of the amplified $\beta$ gene (a), for hybridisation of the products to an internal DNA probe (b), for binding of an anti-c ${ }^{\beta}$ $\mathrm{MAb}$ (c) and for human $\operatorname{IgA} \mathrm{Fc}$ fragment binding (d). Strains analysed are indicated at the top of each lane (see Table 2).

were generated with the MAb, whereas strain nos. 913 failed to bind IgA (Fig. 2d).

For further testing of surface anchoring of $c^{\beta}$, the anti$\mathrm{c}^{\beta}$ MAb was absorbed by whole cells of all the isolates shown in Table 2 and then tested for antibody levels against the A909 $c^{\beta}$ protein. Strains 1 and 3-8 removed the anti- $\mathrm{c}^{\beta}$ antibodies, corresponding to $\mathrm{OD}_{495}$ reductions which ranged from 70 to $90 \%$, whereas strains 2 and 9-15 gave antibody absorption results corresponding to $\mathrm{OD}_{495}$ reductions of $<5 \%$. These results accord with the FAT results and strongly indicate that strains 9-15 did not possess surfacebound $\mathrm{c}^{\beta}$.

As the $\mathrm{c}^{\beta}$ protein is secreted by GBS [21], supernates of fluid cultures of all of the strain nos. 1-15 were examined. Concentrated (50-fold) culture supernates were tested in a sandwich ELISA in which IgA was the capturing immunoglobulin. Strain nos. 1, 3-8 and 14-15 showed MAb-binding corresponding to $\mathrm{OD}_{495}$ recordings in the range $0.800-1.000$ above the background. MAb-binding was not recorded when supernates of strains 2 and $9-13$ were tested. Thus, all the 
$\mathrm{c}^{\beta}$-producing strains secreted the protein. Strains $9-$ 13, negative for $\mathrm{c}^{\beta}$ in Western blotting, showed no $\mathrm{c}^{\beta}$ secretion. This was confirmed in experiments in which the concentrated supernates were used for coating in an indirect ELISA.

Production of $\mathrm{c}^{\beta}$ defective in $\operatorname{Ig} \mathrm{A}$-binding has been reported [16, 17]. The study tested if $\mathrm{c}^{\beta}$ with deficiency in both $\operatorname{IgA}$ and MAb-binding might exist. Strains 1-15 were examined with polyclonal anti-c ${ }^{\beta}$ serum in experiments similar to those performed with the anti- $\mathrm{c}^{\beta} \mathrm{MAb}$, the FAT, immunoblotting, absorption and testing of culture supernates. In all experiments the results correlated with those obtained by probing with MAb or IgA. These results substantiate the assumption that the $\beta$-PCR positive strains $(9-13)$ did not express $\mathrm{c}^{\beta}$ protein and that the $\mathrm{c}^{\beta}$ expressed by strains 14 and 15 was not anchored to the bacterial cell surface.

\section{Discussion}

The serogroup B polysaccharide is specific for $S$. agalactiae. However, these bacteria include a large number of variants based on genotypic or phenotypic characters $[8,22,23]$. In classification based on phenotypic markers, identification of the capsular antigens which define serotype and of strain-variable and surface-localised proteins which define subtypes, have been used most widely. With regard to the strainvariable protein $\mathrm{c}^{\beta}$, strains have been categorised as either $\mathrm{c}^{\beta}$ positive or $\mathrm{c}^{\beta}$ negative by immunological tests. However, the present study has provided evidence of the heterogeneity of $c^{\beta}$ and the gene encoding this protein.

The present study found that all 16 strains which tested FAT-positive for $\mathrm{c}^{\beta}$ were also $\beta$-PCR positive, producing a PCR product close to the estimated size of $604 \mathrm{bp}$. The regularity by which FAT-positive strains generated the $\beta$-PCR product correlates with the findings by other investigators who used a different primer set, which resulted in a 592-bp fragment of the $\beta$ gene [24]. In immunoblotting, the $\mathrm{FAT}^{+} / \beta-\mathrm{PCR}^{+}$strains showed a major $\mathrm{c}^{\beta}$ band of $120 \mathrm{kDa}$ which is lower than the $c \cdot 130-\mathrm{kDa} \mathrm{c}^{\beta}$ band described by other investigators $[13,25]$ and the theoretical estimate of a $\mathrm{M}_{\mathrm{r}}$ of 126.841 Da based on sequence analysis [15]. Minor diversity of the $M_{r}$ estimate may be due to the methodology, as a comparatively high polyacrylamide concentration $(12 \%)$ in SDS-PAGE and a low molecular-weight standard were used.

Surprisingly, seven of 34 GBS strains which were FAT-negative for $\mathrm{c}^{\beta}$, generated a PCR product in the $\beta$-PCR. Six of these strains produced a product that was indistinguishable from the 620 -bp product of the $\mathrm{FAT}^{+} / \beta-\mathrm{PCR}^{+}$strains; whereas one strain (no. 14) generated a 1330 -bp product. The $\beta$ gene abnormality of strain 14 was substantiated by failure of its PCR product to hybridise to the DNA probe which targeted an internal stretch of the amplified gene fragment. Strain 14 also produced an $\operatorname{IgA}$ and $\mathrm{c}^{\beta}$ antibodybinding protein, supporting the notion that this strain harboured the $\beta$ gene, although abnormal with a possible insertion segment. The amplification product of the other seven $\mathrm{FAT}^{-} / \beta-\mathrm{PCR}^{+}$strains hybridised to the internal DNA probe, confirming that these strains harboured the $\beta$ gene.

The seven $\mathrm{FAT}^{-} / \beta$ - $\mathrm{PCR}^{+}$strains subdivided into two categories, those that did not produce the $\mathrm{c}^{\beta}$ protein (strains 9-13) and those that produced antibody and IgA-binding proteins (14 and 15). As the former strains generated a normal PCR product, the silent $\beta$ gene in those strains could be due to a defective gene regulatory function. To our knowledge, no data concerning factors that control $\beta$ gene expression are available. Failure to express gene products occurs quite frequently in streptococci $[26,27]$. The $\mathrm{FAT}^{-} / \beta$-PCR ${ }^{+}$strains 14 and 15 expressed gene products, but these products differed from normal $\mathrm{c}^{\beta}$. Firstly, $\mathrm{c}^{\beta}$ of these strains showed a major band of $c$. $94 \mathrm{kDa}$ and c. $84 \mathrm{kDa}$, respectively, well below the $\mathrm{M}_{\mathrm{r}}$ estimate of $120 \mathrm{kDa}$ for normal $\mathrm{c}^{\beta}$. Secondly, none of these proteins was surface-anchored in the bacteria, as shown by the negative FAT and inability of these bacteria to absorb the anti-c $\mathrm{c}^{\beta}$ antibody. However, the abnormal $\mathrm{c}^{\beta}$ proteins were secreted during bacterial growth. Thus, it is likely that the signal peptide on the $\mathrm{N}$-terminus of the protein [15] behaved normally and secured transmembrane transportation of the proteins. The proteins also behaved normally with respect to IgA-binding, indicating the integrity of the IgA binding domains, which are located $\mathrm{N}$-terminally to the cell wall-spanning region $[14,15]$. The reduced $M_{r}$ of these $c^{\beta} \mathrm{s}$ and failure to bind to the bacterial cell surface could be explained by the fact that these proteins were truncated at the $\mathrm{C}$-terminal end, perhaps due to deletions in a proline-rich area $[14,15]$ with a three-residue periodicity in this half of the protein [15]. Such deletions would affect the cell wall and membrane-spanning domains of $\mathrm{c}^{\beta}$ and surfaceanchoring of the protein.

$\beta$ gene amplification has been described previously, but the results were not compared with antibody-based testing [24]. In a recent study, testing of IgA binding by GBS strains and DNA-DNA hybridisation with a $\beta$ gene DNA probe, showed concordant results [28]. The discrepancy between the results of that study and those of the present study may be related to methodological differences or the fact that GBS from different geographical areas were tested, or both. The present study did not detect $\mathrm{c}^{\beta}$-expressing GBS which failed to bind $\operatorname{IgA}$, but only strains $1-15$ were tested for IgA-binding. GBS expressing $\mathrm{c}^{\beta}$ which lack the ability to bind IgA have been reported $[16,17]$, as has 
$\mathrm{c}^{\beta}$ which did not anchor to the bacterial cell surface [17]. Brady and Boyle [17] found that four of $18 \mathrm{c}^{\beta}$. producing strains secreted the protein without bacterial binding. They found that the unbound but secreted $\mathrm{c}^{\beta_{\mathrm{S}}}$ were low mol.wt proteins in the range $38-55 \mathrm{kDa}$, well below the $M_{r} s$ of similar $c^{\beta}$ described in this study; although even these had reduced $M_{r} s$. The present study substantiates the findings by other investigators $[16,17]$ that a number of variations may affect the GBS $\mathrm{c}^{\beta}$ protein. In addition, the present studies have demonstrated the existence of GBS with unexpressed $\beta$ gene or with a $\beta$ gene with major abnormality.

The $\mathrm{c}^{\beta}$ protein is important in the serological typing of GBS, which, in this laboratory, is based on FAT with whole cells of the bacteria. For $\mathrm{c}^{\beta}$ detection, this test requires surface-anchoring of the proteins. More GBS strains will test positive for $\mathrm{c}^{\beta}$ if methods which detect the protein irrespective of cell surface binding are used; still more strains will test positive if $\mathrm{c}^{\beta}$ protein detection is replaced by $\beta$ gene detection. Of the 50 isolates examined, 16 of $50(32 \%), 18$ of 50 $(36 \%)$ and 23 of $50(46 \%)$, respectively, would show positive results in the three methodological approaches outlined above. This must be taken into consideration in the selection of test methods for typing of GBS. As the 50 strains included in the present study were selected from a diverse collection of clinical isolates on the basis of FAT results for $c^{\beta}$ expression and capsular antigen type, the prevalence of the various $\mathrm{c}^{\beta}$ and $\beta$ gene variants may differ from that of the whole strain collection.

As the GBS $\mathrm{c}^{\beta}$ protein is a target for protective antibodies [4, 11, 12], this protein has been proposed as a vaccine candidate, either unconjugated or as a carrier protein in a capsular polysaccharide- $\mathrm{c}^{\beta}$ conjugate vaccine [29]. Although the protective $\mathrm{c}^{\beta}$ epitopes have not been mapped they are probably located on the N-terminal side of the cell wallspanning region which we believe are absent in the defective $\mathrm{c}^{\beta}$ proteins described in this study. In that case, the defective proteins should possess the protective epitopes. However, it remains to be examined if immunisation with defective $\mathrm{c}^{\beta}$ will induce protective immunity and if these proteins could have advantages over normal $\mathrm{c}^{\beta}$ in a protein or conjugate vaccine.

These findings have demonstrated the existence of GBS with the following categories of $\beta$ gene and $c^{\beta}$ protein variations: (1) strains (16 of 50) that harboured the gene and regularly expressed surface-anchored $\mathrm{c}^{\beta}$; (2) strains ( 5 of 50) that harboured the gene but failed to express $c^{\beta}$; (3) strains ( 2 of 50 ) that harboured the gene but expressed an abnormal $\mathrm{c}^{\beta}$; (4) strains $(27$ of 50) without $\beta$ gene and $c^{\beta}$ expression. One strain within the third category possessed an abnormal $\beta$ gene. Our explanations of some of the findings are speculative. Further experiments are required to elucidate the $\beta$ gene and $\mathrm{c}^{\beta}$ protein variations and if these variations influence virulence, GBS carriage or disease.

We are grateful to Grethe Iversen and Randi Valsoe Lyng for technical assistance.

\section{References}

1. Blumberg HM, Stephens DS, Modansky M et al. Invasive Group B streptococcal disease: the emergence of serotype V. $J$ Infect Dis 1996; 173: 365-373.

2. Brady LJ, Daphtary UD, Ayoub EM, Boyle MDP. Two novel antigens associated with group $\mathrm{B}$ streptococci identified by a rapid two-stage radioimmunoassay. $J$ lnfect Dis 1988; 158: 965-972.

3. Bevanger L, Iversen O-J, Naess AI. Characterization of the $\alpha$ antigen of the $c$ proteins of group B streptococci (GBS) using a murine monoclonal antibody. APMIS 1992; 100: 57-62.

4. Madoff LC, Michel JL, Kasper DL. A monoclonal antibody identifies a protective c-protein alfa-antigen epitope in group B streptococci. Infect Immun 1991; 59: 204-210.

5. Naess AI, Bevanger L, Iversen O-J, Maeland JA. Evaluation of monoclonal antibodies in serovar classification of group B streptococci (GBS). APMIS 1991; 99: 1058-1060.

6. Bevanger L, Kvam AI, Maeland JA. A Streptococcus agalacitae $\mathrm{R}$ protein analysed by polyclonal and monoclonal antibodes. APMIS 1995; 103: 731-736.

7. Ricci ML, von Hunolstein C, Gomez MJ, Parisi L, Tissi L, Orefici G. Protective activity of a muririe monoclonal antibody against acute and chronic experimental infection with type IV group B streptococcus. J Med Microbiol 1996; 44: 475-481.

8. Kvam AI, Efstratiou A, Bevanger L et al. Distribution of serovariants of group B streptococci in isolates from England and Norway. $J$ Med Microbiol 1995; 42: 246-250.

9. Payne NR, Ferrieri P. The relation of the Ibc protein antigen to the opsonization differences between strains of type II group B streptococci. J Infect Dis 1985; 151: 672-681.

10. Payne NR, Kim Y, Ferrieri P. Effect of differences in antibody and complement requirements on phagocytic uptake and intracellular killing of ' $c$ ' protein-positive and -negative strains of type II group B streptococci. Infect Immun 1987; 55: $1243-$ 1251 .

11. Bevanger L, Naess AI. Mouse-protective antibodies against the Ibc proteins of group B streptococci. APMIS 1985; 93: $121-$ 124.

12. Michel JL, Madoff LC, Kling DE, Kasper DL, Ausubel FM. Cloned alpha and beta c-protein antigens of group B streptococci elicit protective immunity: Infect Immun 1991; 59: $2023-2028$.

13. Russell-Jones GJ, Gotschlich EC, Blake MS. A surface receptor specific for human IgA on group B streptococci possessing the Ibc protein antigen. J Exp Med 1984; 160: 1467-1475.

14. Hedén L-O, Frithz E, Lindahl G. Molecular characterization of an IgA receptor from group B streptococci: sequence of the gene, identification of a proline-rich region with unique structure and isolation of N-terminal fragments with IgAbinding capacity, Eur J Immunol 1991: 21: 1481-1490.

15. Jerlström PG, Chhatwal GS, Timmis $\mathrm{KN}$. The IgA-binding $\beta$ antigen of the $\mathrm{c}$ protein complex of group B streptococci: sequence determination of its gene and detection of two binding regions. Mol Microbiol 1991; 5: 843-849.

16. Jerlström PG, Talay SR, Valentin-Weigand P, Timmis KN, Chhatwal GS. Identification of an immunoglobulin A binding motif located in the $\beta$-antigen of the $c$ protein complex of group B streptococci. Infect Immun 1996; 64: 2787-2793.

17. Brady LJ, Boyle MDP. Identification of non-immunoglobulin A-Fc-binding forms and low-molecular-weight secreted forms of the group B streptococcal $\beta$ antigen. Infect Immun 1989; 57: 1573-1581.

18. Bevanger L, Maeland JA. Complete and incomplete Ibc protein fraction in group B streptococci. Acta Pathol Microbiol Scand Sect B 1979; 87: 51-54.

19. Bevanger L, Maeland JA. Type classification of group B 
streptococci by the fluorescent antibody test. Acta Pathol Microbiol Scand Sect B 1977; 85: 357-362.

20. Brakstad OG, Aasbakk K, Maeland JA. Detection of Staphylococcus aureus by polymerase chain reaction amplification of the nuc gene. J Clin Microbiol 1992; 30: 1654-1660.

21. Valtonen MV, Kasper DL, Levy NJ. Isolation of a C (Ibc) protein from group B Streptococcus which elicits mouse protective antibody. Microb Pathog 1986; 1: 191-204.

22. Blumberg HM, Stephens DS, Licitra C et al. Molecular epidemiology of group B streptococcal infections: use of restriction endonuclease analysis of chromosomal DNA and DNA restriction fragment length polymorphisms of ribosomal RNA genes (ribotyping). $J$ Infect Dis 1992; 166: 574-579.

23. Helmig R, Uldbjerg N, Boris J, Kilian M. Clonal analysis of Streptococcus agalactiae isolated from infants with neonatal sepsis or meningitis and their mothers and from healthy pregnant women. $J$ Infect Dis 1993; 168: 904-909.

24. Mawn JA, Simpson AJ, Heard SR. Detection of the $C$ protein gene among group B streptococci using PCR. J Clin Pathol
1993; 46: 633-636.

25. Cleat RH, Timmis KN. Cloning and expression in Escherichia coli of the Ibc protein genes of group B streptococci: binding of human immunoglobulin $\mathrm{A}$ to the beta antigen. Infect Immun 1987; 55: 1151-1155.

26. Huang T-T, Malke H, Ferretti JJ. Heterogeneity of the streptokinase gene in group A streptococci. Infect Immun 1989; 57: 502-506.

27. Podbielski A, Blankenstein $O$, Lütticken R. Molecular characterization of the $c f b$ gene encoding group B streptococcal CAMP-factor. Med Microbiol Immunol 1994; 183: 239-256.

28. Dmitriev AV, Suvorov AN, Schalen C, Totolian AA. Program Abstr. 13th Lancefield International Symposium on Streptococci and Streptococcal Diseases 1996; Abstract P143.

29. Madoff LC, Paoletti LC, Tai JY, Kasper DL. Maternal immunization of mice with group B streptococcal type III polysaccharide-beta $\mathrm{C}$ protein conjugate elicits protective antibody to multiple serotypes. $J$ Clin Invest 1994; 94: $286-292$. 